\title{
TOURISM IN THE COVID-19 PANDEMIC: A PERSPECTIVE WITH SWOT ANALYSIS
}

\author{
Imali N. Fernando \\ Department of Management Sciences, Faculty of Management \\ Uva Wellassa University of Sri Lanka, Sri Lanka
}

\begin{abstract}
Over recent history, a huge number of diseases affected the human race, whereas the Novel Coronavirus or Covid-19, remains the utmost noticeable pandemic disease. The virus spreads with a distinct composition with a substantial concentration whereas people around the biosphere were locked, imposed social distancing rules, and restricted human mobility. Tourism considered a vital economic sector and contributes foreign exchange earnings for a large number of countries. Tourism bonds people with nature, cultures, livelihood, and entertainment by inspiring lives. Consequently, international tourist arrivals have been declined by $70 \%$ to $75 \%$ ratio during the year 2020, within the first and second waves of the Covid-19 Pandemic. Since the sector is more vulnerable to external environmental shocks, the outcome of this downturn is severely affecting numerous economies, specially where the main foreign exchange earnings is Tourism. Therefore, the author discusses the main highlights of the downturn, followed by Strengths, weaknesses, Opportunities, and Threats (SWOT Analysis) as a way forwarding strategy for the Tourism in the Pandemic.
\end{abstract}

Keywords: Covid-19 Pandemic, economic downturn, external environmental shock, SWOT analysis, Tourism

\section{Introduction}

In known history, a large number of diseases affected the human race, whereas the novel Coronavirus or COVID-19, remains the most prominent pandemic disease in the recent past. The virus spreads with a distinct composition with a considerable intensity whereas people around the world were locked to their own houses, imposing social distancing rules and restricting human mobility. According to scholars, (Li et al., 2020) at its outset, COVID-19 spread from a Seafood market located in Wuhan- Hubei Province, then spread among Hubei province to the whole of China. This sudden shock leads the medical sector and scientific community around the globe to search for a solution whereas the hotspots were locked down. A huge number of patients were reported from 58 different countries within three months of its spread, which later created a terrifying pandemic for the entire globe (Li et al., 2020). Novel Coronavirus first reported in the latter part of the year 2019 , continued the first wave during 2020 , and later created a severe vicious second wave around the world, where affecting severely by destructing the economies around the world. As a result, the social activities of the human was restricted by imposing strict rules, due to the high ratios of positive cases. According to Huang et al., (2020), the virus is particularly fatal for the elderly community and people with the weaker immune system.

According to the World Health Organization (WHO), the mechanism of transmitting COVID-19 between people takes place in many different forms, through direct communication with the carrier of the disease or through the physical touch of a surface or an object that has contacted by the carrier (Zhao et al., 2020). Therefore, medical advice recommended to check up on any of the objects that consist of continuous hand washing, hand and surface sanitizing, and in addition restricted touching the face frequently. Moreover, continuous usage of a protective face mask and the maintaining of a 
reasonable gap of more than a meter between human gatherings. In addition to environmental controls reflected in the establishment of appropriate spaces, to guarantee that individuals do not mix or gathering for a narrow location (Zhao et al., 2020).

Therefore this article focus of a perspective of the Global Tourism behavior during Covid-19 pandemic. Moreover, the author has incorporated a Strengths, weaknesses, Opportunities, and Threats (SWOT) analysis for the Global Tourism within the Pandemic.

\section{Tourism as a Vital Economic Force}

Tourism counts as one of the emerging economic sectors and contributes as a main source of foreign exchange earnings for a large number of countries including developing economies (Fernando,2015; Fernando,2020). Tourism is a collection of activities, services, and industries that deliver a travel experience comprising transportation, accommodation, eating and drinking establishments, retail shops, entertainment businesses, and other hospitality services provided for individuals or groups traveling away from home (UNWTO, 2020). Further, it bonds people with nature and natural environment, different cultures, livelihood, entertainment by inspiring lives (Fernando and Long, 2012; Fernando, 2015).

Major reasons facilitate expeditious global tourism growth as such; increased leisure, Greater awareness with a clustered travel programs, Greater prosperity with high expending power, Increased availability of package holidays, Growth of internet/web sources and social media, and enthusiasm to visit culture around the globe Increased number of vehicle ownership and that leads to giving greater freedom (Fernando,2015; Fernando,2020). Herein, Table 1 illustrates the growth of tourism arrivals according to World Tourism Organization (WTO) during recent years.

According to the World Travel and Tourism Council (WTTC) in 2019, Travel \& Tourism's direct, indirect, and induced impact accounted for 8.9 Trillion USD (or $10.3 \%$ ) contribution to the global GDP. This significance highlights further by generating 330 million employments around the world and accounted for 1 in every 10 jobs around the world.

Table 1: Growth of Global Tourism Arrivals and Receipts

\begin{tabular}{|c|c|c|}
\hline Year & $\begin{array}{c}\text { Global } \\
\text { tourism } \\
\text { Arrival } \\
\mathbf{S} \\
\text { (Millio } \\
\mathbf{n})\end{array}$ & $\begin{array}{c}\text { Internati } \\
\text { onal } \\
\text { tourism } \\
\text { receipts } \\
\text { (USD } \\
\text { Billion) }\end{array}$ \\
\hline 2010 & 952 & 975 \\
\hline 2017 & 1,329 & 1,346 \\
\hline 2018 & 1,401 & 1,451 \\
\hline
\end{tabular}

Source: World Tourism Organization (UNWTO), International Tourism Highlights 2019 Edition

Furthermore, during the year 2019, 949 billion USD capital investments accounted within the tourism industry (WTTC, 2020). Interestingly, the massive contributions indicate the significance of global tourism to the economic development of the world economy in the recent past. Tourism contributes drastically to the economic growth in various industries from hospitality, transport, Events, construction, and retail, to small businesses such as restaurants, homestays, bars, cab services, and tourism agents. According to WTTC, within the year 2019, the travel and tourism sector expanded in $3.5 \%$ ratio in the world statistics, by contributing tremendously. Moreover, the sector contributes over 330 million jobs in the world accounting for about $10 \%$ of total employment all around the globe (WTTC, 2020).

\section{Covid-19 Pandemic as an "External Shock"}

The Covid-19 pandemic has changed the world in every imaginable respect and has impacted heavily on all individuals and on every industry, mainly minimizing the people mobilization, including international travel, tourism demand, and hospitality industry (Chang et al.,2020). At present, the world is facing an unprecedented global health, social 
and economic emergency as a result of the novel Corona Virus spread. The impact of the Pandemic will affect almost all industries whereas, Travel and Tourism are among the most affected sectors due to the nature of the social gathering, social contact, and leisure activities. UNWTO predicts a massive fall in international demand amid global travel restrictions among all destinations around the world, including many borders fully closed, some famous cities, and tourism destinations locked down to contain the virus. According to (Chang et al.,2020), the tourism, hospitality, and travel industry are some of the world's largest employers, together with the energy industry, although, unlike the energy industry, the sector is less of a necessity. Therefore the Tourism sector is more sensitive and vulnerable to significant shocks or external shocks as the Covid-19 Pandemic.

The most recent issue of the UNWTO World Tourism Barometer indicates the International tourist arrivals fell by $72 \%$ during the January-October 2020 period compared with the same period of the previous year (the year 2019), curbed by slow virus containment due to the high spreading of the disease, low traveler confidence or noconfidence at all to travel and restrictions on travel or locked-down/ social locked-down due to the pandemic (UNWTO,2020). Since the sector is more vulnerable to external environmental shocks (Fernando and Long, 2012, Fernando 2015), the outcome of this downturn is severely affecting most of the economies, specially where the main foreign exchange earning dominated by Tourism. According to UNWTO statistics, Asia and the Pacific accounted $82 \%$ decrease in tourist arrivals, the Middle East recorded a $73 \%$ decline, Africa recorded a $69 \%$ drop, and Europe and the Americas declined by $68 \%$ during January-October 2020 period (UNWTO,2020).

\section{Pandemic and the downturn of Tourist arrivals}

Consequently, international tourist arrivals have been declined by $70 \%$ to $75 \%$ ratio during the year 2020 within the first wave and second wave of the Covid-19 Pandemic. Further, international tourism shows a downturn to the volumes of 30 years back due to this astonishing declining ratio (UNWTO,2020). This highlights the pandemic results merely on the tourist arrivals, subsequently resulted in the tourism income or foreign exchange earnings of a destination. According to the UNWTO World Tourism Barometer, Pandemic accounted for a $22 \%$ decline in tourist arrivals in the first three months, January -February March 2020 within the virus spread along with the world, by starting from WuhanChina to all over the destinations along with the globe (UNWTO,2020). Figure 1 illustrates the percentage change of Tourist arrivals during the months, January February -March, in the year 2019 compared to the year 2020 .

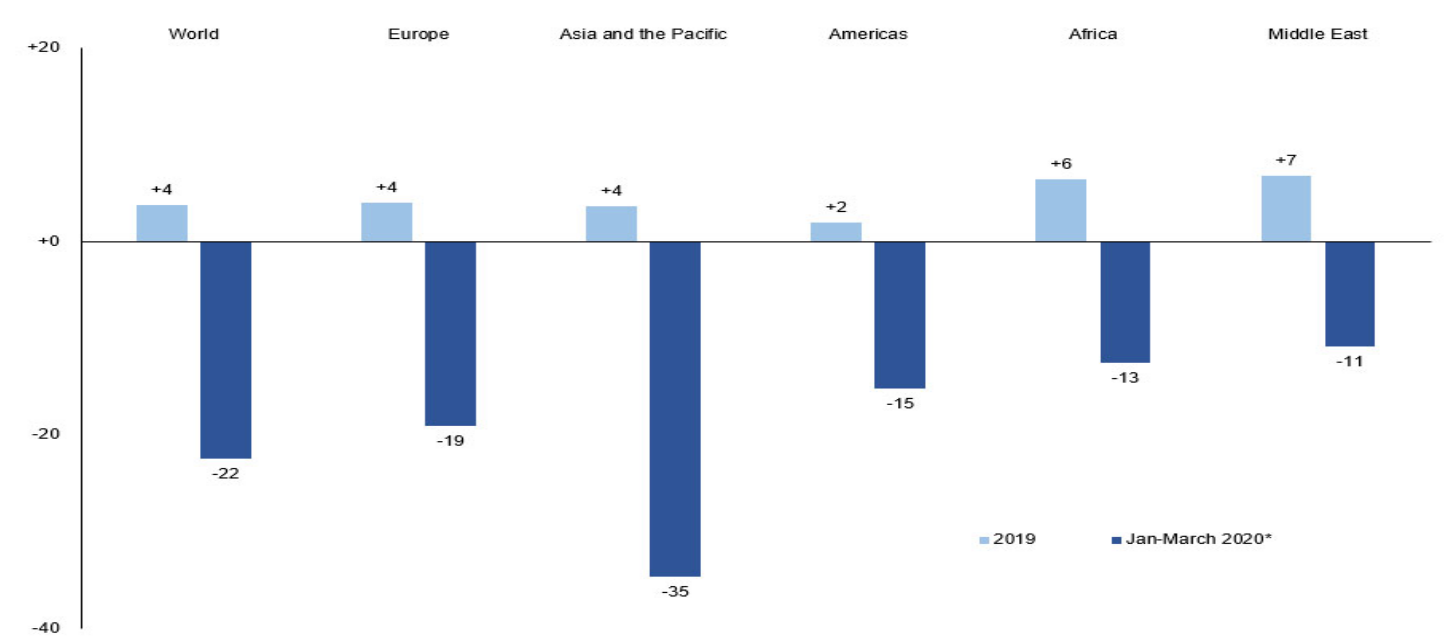

Figure 1: Comparison of \% change of International Tourist Arrivals, 2019 and Q1 2020

(Source : UNWTO, 2020) 
As a result of the first and subsequent waves of the Covid-19 during the year 2020, travel and tourism have literally come to a halt, and the economic activities of the airline industry and hospitality sector have been reduced to a small fraction of what they used to be prior to the pandemic. While some economies are gradually reopening, the overall situation remains volatile due to the high contagiousness of the virus and the lack of immediate treatment or vaccine. According to the UNWTO World Tourism Barometer, almost $100 \%$ of the global destinations have announced travel restrictions as a response to the Covid-19. Moreover, in a global context, 97 destinations or $45 \%$ of the destinations have totally or partially closed their borders for international tourists, whereas 65 destinations (or 30\%) have suspended totally or partially their international flights. Further, 39 destinations, or $18 \%$ out of the total are implementing these guidelines in a differentiated manner, as stated by the UNWTO, banning the entry for foreign passengers from specific countries or regions (UNWTO, 2020). Therefore, the economies that are highly surviving in the tourism receipts or foreign exchange will be in a massive trauma due to the travel restrictions. Figure 2 illustrates the gradual drop in International tourist arrivals within the months January-February -March 2020 with the first wave of the Covid-19 pandemic.

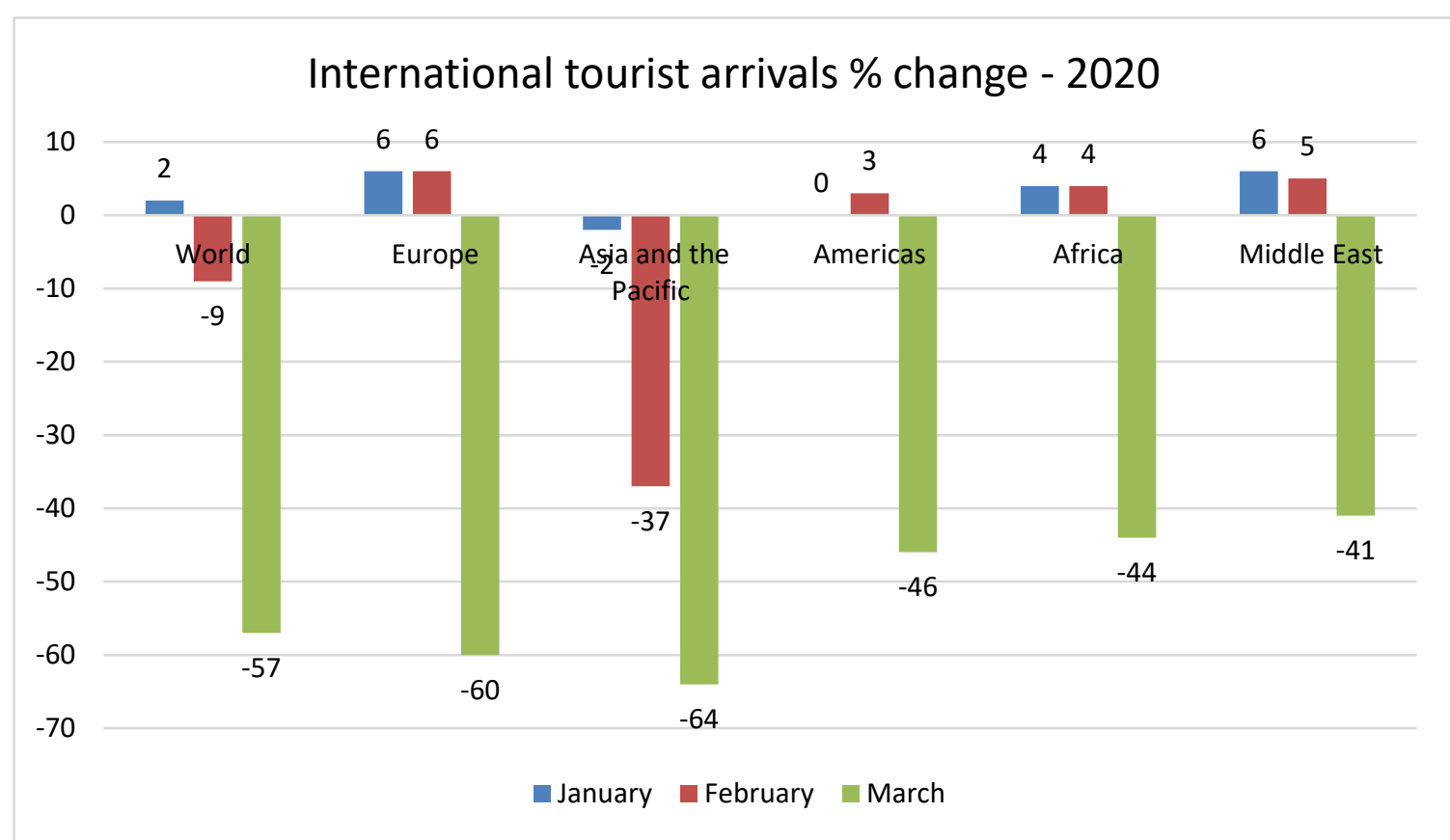

Figure 2: International Tourist Arrivals \% change within January-February -March 2020 (Source: UNWTO,2020)

\section{Pandemic and the Economic Downturn}

In history, a significant number of viruses propagate with viral sources worldwide affecting the human body and changing the impacts, mostly the personal immunity will be the survivor. Despite that, Novel Coronavirus or Covid-19 remains the most prominent pandemic disease, much similar to Spanish flu in this respect, since the virus spreads with a distinct composition with considerable intensity (Fernando et al, 2020). Herein throughout history, with varying intensities, different pandemics had affected the global Tourism and
Hospitality sector. On that contrary, Table 2 is an illustration of recent pandemics and the influences on global tourism.

Table 2 demonstrates how a crisis impacts the sector, or how long it will take to arrive at the normality for the sensitive industry like Hospitality and Tourism. Descriptively, the global economic crisis in the year 2009 devoted almost two years duration (19 months) to return previous volumes, whereas the most affected region, Europe, got 29 months duration for the same. 
Table 2: Previous crisis with impact for the Tourism

\begin{tabular}{|c|c|c|c|}
\hline Crisis & $\begin{array}{r}\text { Sept 11th } \\
\text { Terrorist } \\
\text { attacks } 2001\end{array}$ & $\begin{array}{r}\text { SARS } \\
2003\end{array}$ & $\begin{array}{r}\text { Global } \\
\text { Econ. } \\
\text { Crisis } \\
2009\end{array}$ \\
\hline $\begin{array}{l}\text { World tourists arrivals (\% } \\
\text { change) }\end{array}$ & $+0.1 \%$ & $-0.4 \%$ & $-4.0 \%$ \\
\hline month 0 (zero) & Sept. 2001 & $\begin{array}{r}\text { March } \\
2003\end{array}$ & $\begin{array}{r}\text { Jan. } \\
2009\end{array}$ \\
\hline $\begin{array}{l}\text { Number of months for return } \\
\text { to growth }\end{array}$ & 5 & 5 & 10 \\
\hline $\begin{array}{l}\text { Number of months for return } \\
\text { to previous volumes }\end{array}$ & 14 & 11 & 19 \\
\hline $\begin{array}{l}\text { World receipts (real change, } \\
\% \text { ) }\end{array}$ & $-2.0 \%$ & $-1.7 \%$ & $-5.4 \%$ \\
\hline Most impacted region & Americas & $\begin{array}{r}\text { Asia } \\
\text { Pacific }\end{array}$ & Europe \\
\hline $\begin{array}{l}\text { Region's tourists arrivals (\% } \\
\text { change) }\end{array}$ & $-5.9 \%$ & $-9.4 \%$ & $-5.3 \%$ \\
\hline $\begin{array}{l}\text { Number of months for return } \\
\text { to growth }\end{array}$ & 12 & 7 & 14 \\
\hline $\begin{array}{l}\text { Number of months for return } \\
\text { to previous volumes }\end{array}$ & 42 & 14 & 29 \\
\hline $\begin{array}{l}\text { Region's receipts (real change, } \\
\% \text { ) }\end{array}$ & $-11.1 \%$ & $-8.1 \%$ & $-6.7 \%$ \\
\hline
\end{tabular}

Source: UNWTO,2020

Moreover, the crisis or disaster impact in some cases is problematic to measure economically, specially the social negative externalities. As a sensitive industry, tourism assigns value to various types of assets; climate, fresh air, scenic beauty, waterways, biodiversity, cultural artifacts, landscape as such ensuring the development of less rich areas (Iordache et al.,2010), and nature-based niche markets; Agro-tourism, Tea tourism, gem-minerals and rural tourism (Fernando et al, 2017, Pattiyagedara and Fernando,2020). Despite these values, the Covid-19 Pandemic will provide a massive range of downturn to the sector, where the sector itself bonding people-to-people in every aspect. The benefits of tourism are widespread, whereas promoting inter and intra-regional disparity elimination, poverty reduction specially within small island destinations, urbanizing of rural, communication and technology enhancements, road development, and promoting country "Branding". On that contrary, the main objective of tourism is to enhance the quality of the livelihood of the residents (Iordache et al.,2010; Kim and
Dwyer, 2003; Fernando,2012). Due to the massive contribution from the Tourism sector as a source of foreign exchange earner in many advanced and emerging economies, according to UNWTO, the pandemic results in the following impacts; (a) Destinations that have a high share of tourism income in foreign exchange earnings, employment creation, and investments, are particularly vulnerable (b) Small Island Developing States (SIDS) might get massive economic downturns.

Therefore, this paper presents Strengths, weaknesses, Opportunities, and Threats (SWOT analysis) as a way forwarding strategy for the Hospitality and Tourism sector within the face of the Covid-19 Pandemic. Figure 3 illustrates the SWOT analysis of the global tourism within the Pandemic.

Author presents the Strengths, weaknesses, Opportunities and Threats (SWOT analysis) descriptively for the Hospitality and Tourism sector amid the face of Covid-19 Pandemic. 


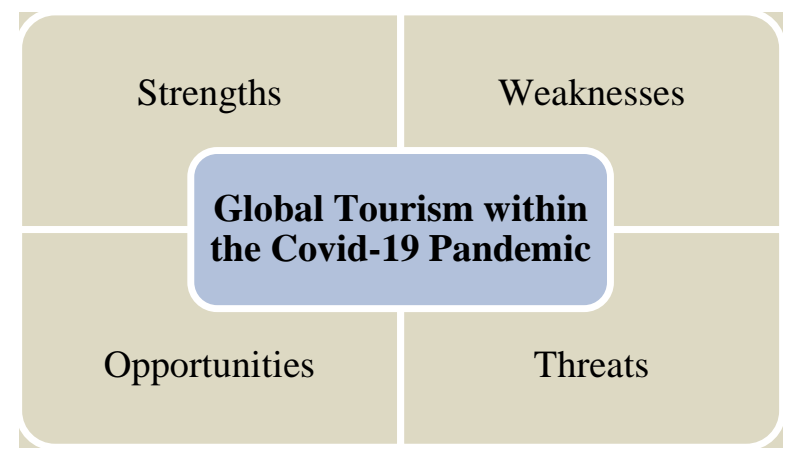

Figure 3: SWOT analysis

(Source: own construction)

\section{Strengths within the Pandemic}

1. Proven resilience within historical disasters such as during the major economic crisis, Terrorist attacks

2. Booming the domestic tourism within the destinations: most of the marketing programs cater to domestic travels

3. Adaptation capacity to the pandemic such as medical, safety, and hygiene safety measures, training of medical practitioners

4. Promoting Special Interest Tourism (SIT): Tea Tourism, Ayurvedic Tourism, Health and Wellness tourism, Naturebased travel

5. Clustering the small groups

6. More responsible tourist behavior: specially maintaining the social distance rules, health precautions, and selfsanitation

7. Promoting short distance travels and tourism niche-markets

8. Destination Management Organizations (DMO)'s and Government support to the Tourism sector: country branding, image building, and "tourism bubble concept"

\section{Weaknesses within the Pandemic}

1. High risk for MICE tourism: specially the Events segment

2. Highest impact for Air traveling results major Airline Companies to collapsed, loss of employment and income

3. Major global tourist markets and hotspots were highly affected: specially the European continent

4. Demand for the sector reduced due to social distancing rules imposed, unsafety during Air travel, and regional factors
5. Tourist perception towards the traveling: perceive as a high risk

6. Residents perception towards the foreign travelers: perceive as a high risk

\section{Opportunities within the Pandemic}

1. The upbringing of innovating practices: virtual tours and out-door entertainments

2. Investing more in health and wellness tourism, Ayurvedic Tourism, Tea tourism

3. Novel innovative business models: hybrid models with human touch and technology

4. Promoting sustainable tourism: nature travels, rural tourism niche markets

5. Diversification of the domestic tourism segment: nature trails, bio-diversity, rural tourism, Agro-farming related tourism

6. Small Island destinations: innovative focus and promotion of niche-markets

7. Orientation for less-identified niches as novelties: lagoon based travels, Spiritual tourism segments

8. Managing events innovatively: promoting outdoor events, outdoor weddings and functions, culture trails

9. Social media platforms and online media promotions

10. Perception on lifestyle : more directs for healthy food patterns, traditional way of living, explore more nature and fresh air

\section{Threats within the Pandemic}

1. Global Economic Recession

2. Direct and indirect employment loss in tourism: Tour guides, Homestays, Hotels, Event Planners, etc.

3. Downturn of the global business: specially Micro, Small and Medium Enterprises (MSME)

4. Lower disposable income of the people: diminishing the travel intention, less demand for leisure

5. Negative perception: due to lessprediction of the virus spreading, high contagious virus

6. Social distancing, travel restrictions, and locked-down status of the major destinations 
7. Uncertainty and social panic: vaccine to Covid-19

The author wishes future researchers would cater towards the country-specific determinants within the SWOT analysis amid the economic downturn of the Pandemic. Therefore this SWOT analysis could be a baseline for a more extensive destinationcatered empirical research work on the Tourism industry within the face of Pandemic.

\section{Conclusion}

Tourism considered as a vital economic force as well a sector which could ties people with nature, cultures, livelihood, and entertainment by inspiring the lives. Due to the Covid-19 Pandemic, consequently, global tourist arrivals have been dropped by $70 \%$ to $75 \%$ ratio during the year 2020 . Tourism sector is more vulnerable to the external environmental shocks as such Pandemics, civil war, Disasters etc., the outcome of this downturn is severely affecting numerous economies around the world, specially where the tourism income plays a significant role within the foreign exchange earnings. Hence, this article is a perspective where the author discusses the main highlights of the Tourism downturn in global context, followed by Strengths, weaknesses, Opportunities, and Threats Analysis (SWOT Analysis) as a way forwarding strategy for the Tourism in the Pandemic.

Author is a Professor in the discipline of Management, attached to the Department of Management Sciences, Faculty of Management, Uva Wellassa University of Sri Lanka.

\section{References}

Chang C, McAleer M. and Vicente R. (2020), A Charter for Sustainable Tourism after COVID-19, Sustainability 2020, 12, 3671

Fernando Imali N., (2015)., What competitive strategies way forward the regional competitiveness? A comparative Economic approach to Sri Lankan Tourism, International Journal of Business and Management, 10 (4), 178

Fernando Imali N., (2020). Tourism competitiveness by shift-share analysis to way-forward Destination Management: A case study for Sri Lanka, Journal of Tourism and Services, 11 (21), 88-102

Fernando Imali N., Wei Long, (2012). New conceptual model on cluster competitiveness: A new paradigm for Tourism? International Journal of Business and Management, Canadian Center of Science and Education, 7(9)

Fernando Imali N.,(2012). Towards an Integrated Conceptual Model on Tourism Competitiveness: Does Clustering Way Forward? International Journal of Research in Commerce and Management, II (XI)

Fernando P.I.N., Rajapaksha R. and K. Kumari , Tea Tourism as a marketing tool : a strategy to develop the image of Sri Lanka as an attractive tourism destination, Kelaniya Journal of Management, 5 (2), 2017

Huang, C., Wang, Y., Li, X., Ren, L., Zhao, J., Hu, Y., Zhang, L., Fan, G., Xu, J., Gu, X., Cheng, Z., Yu, T., Xia, J., Wei, Y., Wu, W., Xie, X., Yin, W., Li, H., Liu, M., ... Cao, B. (2020). Clinical features of patients infected with 2019 novel coronavirus in Wuhan, China. The Lancet, 395(10223), 497-506. https://doi.org/10.1016/S01406736(20)30183-5

Iordache C., Ciochina I. and Asandei M.,(2010). Clusters-Tourism activity increase competitiveness support, Theoretical and Applied Economics, XVII (5), 99-112

Iordache C., Ciochina I. and Asandei M.,(2010). Clusters-Tourism activity increase competitiveness support, Theoretical and Applied Economics, XVII (5), 99-112

Kim C. and L. Dwyer,(2003).Destination Competitiveness and Bilateral Tourism flows between Australia and Korea, The Journal of Tourism Studies, 14 (2), 55-67 
Kim C. and L. Dwyer,(2003).Destination Competitiveness and Bilateral Tourism flows between Australia and Korea, The Journal of Tourism Studies, 14 (2), 5567

Kock F, Astrid N., Josiassen A. , Assaf G. and M. Tsionas (2020), Understanding the COVID-19 tourist psyche: The Evolutionary Tourism Paradigm, Elsevier Public Health Emergency Collection, November 2020;85

Li, X., Song, Y., Wong, G., \& Cui, J. (2020). Bat origin of a new human coronavirus: there and back again. Science China Life Sciences, 63(3), 461-462. https://doi.org/10.1007/s11427-020$1645-7$

Pattiyagedara S. and Fernando P.I.N, (2020), Rural Tourism Niche-market as a development strategy on rural community : Refernce to Hiriwadunna Village Track, Meemure and Heeloya Knuckles Valley Tourism Village, Sri Lanka, Sri Lanka Journal of
Management Studies, 2(1), 87-103

UNWTO, World Tourism Barometer (2020), Special focus on the Impact of COVID19 (accessed on 23 January 2021)

World Tourism Organization (UNWTO), International Tourism Highlights 2019 Edition, (accessed on 23 January 2021)

WTTC. (2020). Economic Impact Reports. World Travel and Tourism Council, https://wttc.org/Research/EconomicImpact

Zhao, S., Lin, Q., Ran, J., Musa, S. S., Yang, G., Wang, W., Lou, Y., Gao, D., Yang, L., He, D., \& Wang, M. H. (2020). Preliminary estimation of the basic reproduction number of novel coronavirus (2019-nCoV) in China, from 2019 to 2020: A data-driven analysis in the early phase of the outbreak. International Journal of Infectious Diseases, 92, 214-217. https://doi.org/10.1016/j.ijid.2020.01. $\underline{050}$ 